\title{
The content of linoleic and alpha-linolenic acid in different types of Yerba Mate, depending on country of origin and the conditions of the infusion
}

\section{Zawartość kwasu linolowego i alfa-linolenowego w zależności od kraju pochodzenia i warunków parzenia w różnych typach herbaty Yerba Mate}

\author{
Dominika Maciejewska1', Agnieszka Łukomska1', Karolina Jakubczyk¹, Irena Baranowska-Bosiacka², \\ Ewa Stachowska1', Dariusz Chlubek², Izabela Gutowska1
}

${ }^{1}$ Zakład Biochemii i Żywienia Człowieka Pomorskiego Uniwersytetu Medycznego w Szczecinie

ul. Broniewskiego 24, 71-460 Szczecin

Kierownik: prof. dr hab. n. med. Ewa Stachowska

${ }^{2}$ Zakład Biochemii Pomorskiego Uniwersytetu Medycznego w Szczecinie

al. Powstancow Wlkp. 72, 70-111 Szczecin

Kierownik: prof. dr hab. n. med. Dariusz Chlubek

\section{SUMMARY}

Introduction: Yerba Mate (Ilex paraguariensis) is one of the most widely consumed teas in South America. It is becoming more and more popular in North America and Europe.

The aim of the study was a qualitative and quantitative analysis of the fatty acids from the omega 6 and omega 3 families in Yerba Mate teas.

Methods: There were two types of infusions - cold and hot (three brews from the same leaves). Yerba Mate was incubated for $10 \mathrm{~min}$, then $2 \mathrm{~mL}$ of the brew was taken for isolation. Fatty acids were extracted by the Folch method. The resulting fatty acid methyl esters were analyzed using gas chromatography.

Results: The analysis of fatty acids in the infusions of Yerba Mate showed a significant amount of linoleic acid (LA) and alpha- -linolenic acids (ALA). The concentrations of these acids present in fresh infusions were approx. $250 \mathrm{ug} / \mathrm{mL}$ for infusion of LA, and $600 \mathrm{ug} / \mathrm{mL}$ infusion for ALA. With the subsequent brew using the same leaves the amount of fatty acids decreased significantly $(\mathrm{p}<0.01)$.

Conclusions: Drinking Yerba Mate can supply ALA and LA, which are essential in a well-balanced diet. For individuals who regularly consume Yerba Mate, it can be an important source of polyunsaturated fatty acids (PUFA) supplementation. The most preferred way to brew the tea is cold infusion, which delivers the highest dose of unchanged PUFAs. This method of brewing also reduces the gastrointestinal exposure to high temperature, and thus reduces the risk of cancer incidence.

Key words: alpha-linolenic acid, linoleic acid, Yerba Mate, omega 3, omega 6 .

\section{STRESZCZENIE}

Wstęp: Yerba Mate (Ilex paraguariensis) jest jedną z najczęściej spożywanych herbat w Ameryce południowej. Staje się ona coraz bardziej popularna również w krajach Ameryki Północnej oraz w Europie. Badania naukowe wskazują, iż pomaga obniżyć poziom cholesterolu, działa ochronnie na wątrobę oraz stymuluje centralny układ nerwowy. Doniesiono również o jej protekcyjnym wpływie na choroby układu krążenia i otyłość.

Celem badania była analiza kwasów tłuszczowych z rodziny omega 6 oraz omega 3 w naparach mieszanek Yerba Mate. Metody: Napary zostały przygotowane poprzez odważenie $10 \mathrm{~g}$ Yerba Mate i zalanie $50 \mathrm{~mL}$ wody destylowanej. Wykonano dwa rodzaje naparów - zimny oraz gorące (kilka zaparzeń tego samego suszu). Przygotowaną w ten sposób Yerba Mate inkubowano przez $10 \mathrm{~min}$, a następnie poddano izolacji. Kwasy tłuszczowe zostały wyekstrahowane za pomocą metody
Folcha. Powstałe estry metylowe kwasów tłuszczowych zostały przeanalizowane na chromatografie gazowym.

Wyniki: Analiza kwasów tłuszowych w naparach mieszanek Yerba Mate wykazała znaczną ilość kwasu linolowego oraz alfa-linolenowego. Stężenia tych kwasów obecne w świeżym, wodnym naparze herbaty wynosiły ok. $250 \mathrm{ug} / \mathrm{mL}$ naparu dla kwasu linolowego oraz $600 \mathrm{ug} / \mathrm{mL}$ naparu dla kwasu alfa-linolenowego. Wraz z kolejnymi zalaniami suszu ilość kwasów tłuszczowych spadała w sposób istotny statystycznie $(\mathrm{p}<0,01)$.

Wnioski: Nie wykazano istotnej różnicy między ilością kwasu alfa-linolenowego a sposobem parzenia. W przypadku kwasu linolowego ilość ta była istotnie wyższa w zimnym naparze. W żadnym z naparów nie wykazano również istotnych różnic między krajem pochodzenia a ilością kwasów tluszczowych. Słowa kluczowe: kwas alfa-linolenowy, kwas linolowy, Yerba Mate, omega 3, omega 6. 


\section{INTRODUCTION}

Yerba Mate (Ilex paraguariens) is the one of the most widely consumed teas in South America. Most plantations are located in Brazil, Argentina, Paraguay and Uruguay. The amount of Yerba Mate consumption and brewing method is linked with the region of origin. In comparison to other teas, Yerba Mate can be prepared with cold as well as hot water. The water added to the tea should cover all the leaves in a cup. It is estimated that to brew one portion of leaves (approx. $50 \mathrm{~g}$ ), approx. 1 litre of water is needed (total amount of water with subsequent brews) [1].

Mate drinking is becoming more and more popular in North America and Europe. The impact of the consumption of Yerba Mate on the human body is now being considered. Research shows that Mate helps to decrease the concentration of cholesterol, has a protective effect on the liver [2], and stimulates the central nervous system [3]. There are reports about a protective effect on cardiovascular disease [4] and obesity [5]. All of these positive effects can be associated with the presence of many biologically active substances, such as: antioxidants [5] alkaloids, polyphenols, flavonoids, xanthine, amino acids, elements (P, Fe, $\mathrm{Ca}$ ) and vitamins [1]. In vitro studies on human hepatoma cells (HepG2) showed that the Yerba Mate extract has antitumor properties [6]. On the other hand, epidemiological analysis shows a positive correlation between some type of cancers (oral, oropharyngeal, esophageal, laryngeal and bladder) and the consumption of Mate [1].

The human body is able to synthesize monounsaturated fatty acids. These acids come from palmitic and stearic acid metabolism. Further creation of the double bond is possible only in plants. Plants have two specific enzymes $-\Delta 12$ desaturase and $\Delta 15$ desaturase, which catalyze the formation of unsaturated bonds in oleic acid. $\Delta 12$ desaturase creates a double bond between the $12^{\text {th }}$ and $13^{\text {th }}$ carbon atom of oleic acid and form linoleic acid (LA). $\Delta 15$ desaturase adds one more double bound and converts LA to alpha-linolenic acid (ALA). Linoleic acid and ALA are substrates for the further transformation of polyunsaturated fatty acids (PUFA) [7].

Alpha-linolenic acid is an essential fatty acid in the human diet. Alpha-linolenic acid is a precursor of fatty acids from the omega 3 family. It can be found in the following products: rapeseed oil, soybean oil, linseed oil, nuts and fish. Alpha-linolenic acid concentration in plasma phospholipids, cells and tissues is less than $0.5 \%$ of total fatty acids. One of the main roles of this acid is to provide eicosapentaenoic acid and docosahexaenoic acid (DHA). Fatty acids from the omega 3 family, in particularly DHA, has a protective influence for many diseases, such as: cancer, cardiovascular diseases, connective tissue disorders, renal disorders, respiratory disorders, dermatological disorders, cystic fibrosis, Zellweger disease, psychiatric disorders and malaria $[8,9]$.

Linoleic acid is a precursor of the $\mathrm{n} 6$ family. The main sources of this acid are: sunflower oil, corn oil, soybean oil, coconut oil, flaxseed, nuts, soy, and grape seeds. During the enzymatic changes LA is converted to $\gamma$-linolenic acid (DGLA) and then to arachidonic acid (AA). Both DGLA and AA are precursors of eicosanoids, which are important proinflammatory mediators $[10,11,12]$.

\section{MATERIAL AND METHODS}

\section{Material}

We analyzed 12 different types of Yerba Mate. The samples were mixtures of dried leaves and stalks of different varieties of Ilex paraguariensis. Mixtures were divided by country of origin: 3 samples were from Brazil (Erua Mate, Mate Green Regular, Mate Green Mass Energy) 4 from Argentina (La Marced De Monte, Taragui Con Palo, Rosamonte Especial, Taragui), and 5 from Paraguay (Colon Tradicional, Indega Especial, La Mejor, La Potente Bio, Mate Pajarito).

\section{Yerba Mate infusions}

Infusions were prepared with $10 \mathrm{~g}$ of Yerba Mate. There were two types of infusions - cold (room temperature) and hot $\left(85^{\circ} \mathrm{C}\right)$. Both hot and cold infusions were made with $10 \mathrm{~g}$ of dried leaves and $50 \mathrm{~mL}$ of distilled water (to cover all leaves in a cup). Yerba Mate was incubated for $10 \mathrm{~min}$, then $2 \mathrm{~mL}$ of the brew was taken for isolation. In the case of hot infusions $10 \mathrm{~g}$ of dried leaves were brewed three times at $85^{\circ} \mathrm{C}$, with the same incubation time, water volume and brew volume for isolation. In the results, we isolated 4 samples ( 1 from cold and 3 from hot infusions) from each type of Yerba Mate.

\section{Isolation of free fatty acids}

Fatty acids were extracted according to the Folch method [13]. $2 \mathrm{~mL}$ of Yerba Mate infusion was saponified with $1 \mathrm{~mL}$ of $2 \mathrm{M}$ $\mathrm{KOH}$ methanolic solution at $70^{\circ} \mathrm{C}$ for $20 \mathrm{~min}$, and then methylated with $2 \mathrm{~mL} 14 \%$ solution of boron trifluoride in methanol under the same conditions. Then $2 \mathrm{~mL}$ of $\mathrm{n}$-hexane and $10 \mathrm{~mL}$ saturated $\mathrm{NaCl}$ solution were added. $1 \mathrm{~mL}$ of the $\mathrm{n}$-hexane phase was collected for analysis.

\section{Analysis of fatty acid methyl esters}

Gas chromatography was performed using an Agilent Technologies 7890A GC System (supelcowax ${ }^{\mathrm{TM}} 10$ Capillary GC Column $(15 \mathrm{~m} \times 0.10 \mathrm{~mm}, 0.10 \mu \mathrm{m})$; Supelco, Bellefonte, PA, USA). Chromatographic conditions were as follows: the initial temperature was $60^{\circ} \mathrm{C}$ for $0 \mathrm{~min}$, increased at a rate of $40^{\circ} \mathrm{C} / \mathrm{min}$ to $160^{\circ} \mathrm{C}$ (o min), increased at a rate of $30^{\circ} \mathrm{C} / \mathrm{min}$ to $190^{\circ} \mathrm{C}(0.5 \mathrm{~min}$ ), and then increased at a rate of $30^{\circ} \mathrm{C} / \mathrm{min}$ to $230^{\circ} \mathrm{C}$ for $2.6 \mathrm{~min}$, where it was maintained for $4.9 \mathrm{~min}$. The total analysis was approximately $8 \mathrm{~min}$, and the gas flow rate was $0.8 \mathrm{~mL} / \mathrm{min}$ with hydrogen as the carrier gas. Fatty acids were identified by comparing their retention times with those of commercially available standards.

\section{Statistical analysis}

Statistica 7.1 software was used for the statistical analysis, and all results are expressed as mean \pm standard deviation. 
As the distribution in most cases deviated from normal (Shapiro-Wilk test), non-parametric tests were used: the MannWhitney U test for comparisons between groups, and the Wilcoxon matched-pair test for related samples, and $\mathrm{p}<0.05$ was considered statistically significant.

\section{RESULTS}

Analysis of fatty acids in the Yerba Mate infusions showed significant concentrations of LA and ALA. We did not detect other acids from omega 3 or omega 6 families. Graphs show concentrations of LA (Fig. 1) and ALA (Fig. 2), depending on the temperature of brewing. In both acids we found significant differences between successive hot brewing of Mate $(\mathrm{p}<0.01)$. The statistical differences between hot and cold infusions were found only in the concentration of LA $(p<0.05)$.

In addition, there was no difference between the origin of Yerba Mate and the amount of LA and ALA. The results are presented in table (Table 1).

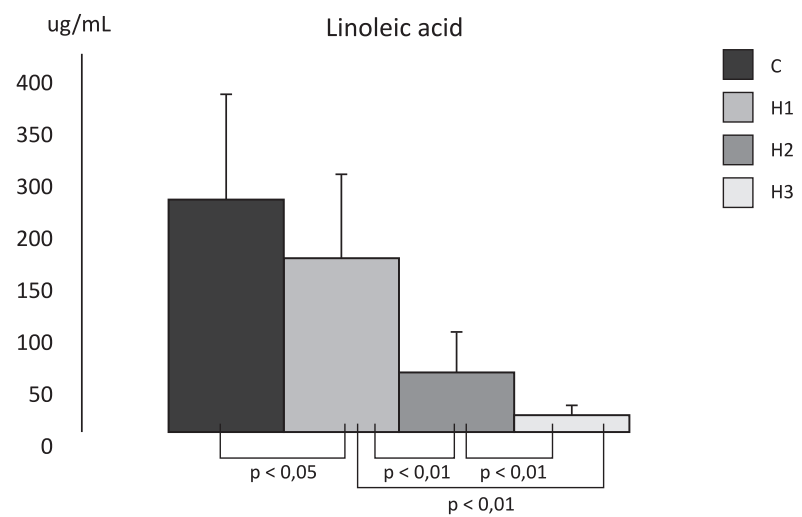

$\mathrm{C}$ - room temperature, $\mathrm{H} 1$ - the first brew at $85^{\circ} \mathrm{C}, \mathrm{H} 2$ - the second brew at $85^{\circ} \mathrm{C}$, $\mathrm{H} 3$ - the third brew at $85^{\circ} \mathrm{C}$

FIGURE 1. Linoleic acid concentration according to the temperature of brewing

\section{DISCUSSION}

The most common polyunsaturated fatty acids present in food are: alpha-linolenic acid and linoleic acid. These acids are essential for the proper functioning of the body [14]. Intake of PUFAs is one of the elements of proper nutrition. Daily intake of ALA, compared to the general population of adults, should be approximately $2 \mathrm{~g} /$ day. For prevention of cardiovascular disease and neurological disorders daily intake of ALA should be approx. $1 \%$ of daily energy intake (E). This amount corresponds to 2-3 g ALA/day for energy intakes 1800-2700 kcal/day [15]. The European Food Safety Authority reports that ALA intake in European countries averages from $0.36 \% \mathrm{E}(0.9 \mathrm{~g} /$ day) to $0.8 \% \mathrm{E}(1.51 \mathrm{~g} /$ day). The minimum daily requirement of LA, which helps to avoid deficiency symptoms, averages $1 \%$ of $\mathrm{E}$. In the case of prevention of cardiovascular diseases the daily requirement should be $4-10 \% \mathrm{E}$, which is approx. 8-30 g LA/day for intakes $1800-2700 \mathrm{kcal} /$ day. In Europe, depending on the country, daily LA intake ranges $3.9-7.1 \% \mathrm{E}[15,16,17,18,19,20]$. An important element in a well-

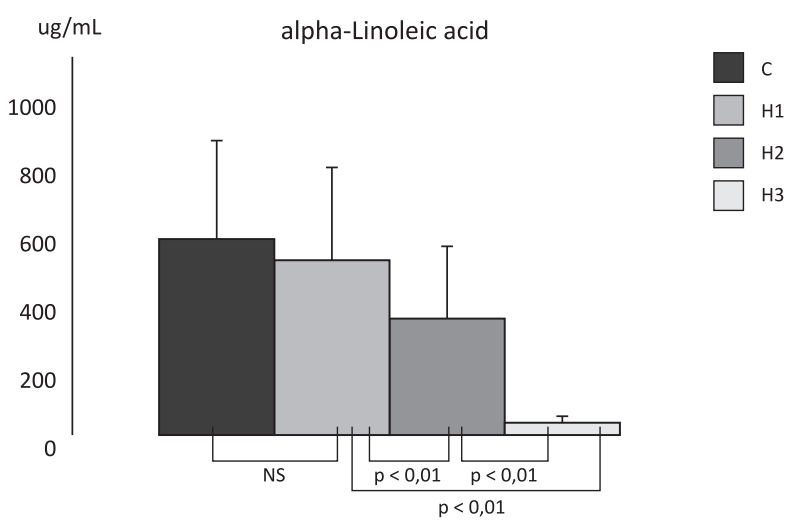

$\mathrm{C}$ - room temperature, $\mathrm{H} 1$ - the first brew at $85^{\circ} \mathrm{C}, \mathrm{H} 2$ - the second brew at $85^{\circ} \mathrm{C}$, $\mathrm{H} 3$ - the third brew at $85^{\circ} \mathrm{C}$

FIGURE 2. Alpha-linoleic acid concentration according to the temperature of brewing

TABLE 1. Average concentrations of fatty acids according to the country of origin and brewing temperature

\begin{tabular}{|c|c|c|c|c|c|c|c|c|}
\hline \multicolumn{9}{|c|}{ Linoleic acid } \\
\hline \multirow[b]{2}{*}{ Country } & \multicolumn{2}{|c|}{ Cold infusion } & \multicolumn{2}{|c|}{ Hot infusion 1} & \multicolumn{2}{|c|}{ Hot infusion 2} & \multicolumn{2}{|c|}{ Hot infusion 3} \\
\hline & $\begin{array}{c}\text { mean } \\
\text { (ug/mL) }\end{array}$ & SD & $\begin{array}{c}\text { mean } \\
\text { (ug/mL) }\end{array}$ & SD & $\begin{array}{c}\text { mean } \\
\text { (ug/mL) }\end{array}$ & SD & $\begin{array}{c}\text { mean } \\
\text { (ug/mL) }\end{array}$ & SD \\
\hline Argentina & 337 & 138 & 223.2 & 69 & 84.6 & 61.9 & 9.4 & 8 \\
\hline Brazil & 256.2 & 37 & 208.8 & 103 & 181.7 & 67.6 & 7.8 & 4.6 \\
\hline Paraguay & 295 & 123.1 & 193.4 & 115.5 & 78.2 & 64 & 8.4 & 3.2 \\
\hline \multicolumn{9}{|c|}{ alpha-Linolenic acid } \\
\hline \multirow[b]{2}{*}{ Country } & \multicolumn{2}{|c|}{ Cold infusion } & \multicolumn{2}{|c|}{ Hot infusion 1} & \multicolumn{2}{|c|}{ Hot infusion 2} & \multicolumn{2}{|c|}{ Hot infusion 3} \\
\hline & $\begin{array}{c}\text { mean } \\
\text { (ug/mL) }\end{array}$ & SD & $\begin{array}{c}\text { mean } \\
\text { (ug/mL) }\end{array}$ & SD & $\begin{array}{c}\text { mean } \\
\text { (ug/mL) }\end{array}$ & SD & $\begin{array}{c}\text { mean } \\
\text { (ug/mL) }\end{array}$ & SD \\
\hline Argentina & 519.9 & 129.6 & 483.7 & 52.6 & 375.9 & 125.5 & 21 & 6.1 \\
\hline Paraguay & 716.5 & 581.2 & 646.6 & 387.1 & 456.5 & 185.4 & 11.8 & 7.7 \\
\hline
\end{tabular}


-balanced diet is the ratio of omega 6 to omega 3 fatty acids supply. Socio-economic change which have been made over the past 100-150 years, dramatically affected changes in the diet in Western countries. Before the technical revolution the omega 6 : omega 3 ratio was approx 1:1 [21]. Increased intake of fat in the diet, reduced consumption of fish, and many other dietary changes caused the ratio of omega 6 to omega 3 estimated at 20-30:1 (omega 6 : omega 3). It turns out that low ratios, such as 2-5:1 (omega 6 : omega 3) have beneficial effects in some disorders. These observations were obtained for the treatment of colorectal cancer, asthma, and rheumatoid arthritis $[21,22]$. Analysis of fatty acids in different types of Yerba Mate has shown significant levels of LA and ALA. The concentrations of the acids present in brews was about. $250 \mu \mathrm{g} / \mathrm{mL}$ of infusion of LA and $600 \mathrm{ug} / \mathrm{mL}$ of infusion of ALA. We also found a low concentration ratio of LA to ALA, which is 1:2.4 (omega 6 : omega 3). It should be noted that drinking 1 litre of Yerba Mate brew (assuming changing the leaves during each brewing), regardless of the country of origin, can partly meet the demand for these acids and lower the ratio of the daily supply of omega 6 : omega 3 . If we assume that the daily demand for alpha-linolenic acid is approx. $2 \mathrm{~g} /$ day, the consumption of 1 litre of fresh brew will supply up to $30 \%$ of the recommended daily intake. The minimum daily dose of linoleic acid preventing symptoms of deficiency is $2 \mathrm{~g}(1 \% \mathrm{E})$ [15] 1 litre of fresh infusion is able to cover approx. $12.5 \%$ of the minimum recommended daily intake. During subsequent brews of the same leaves the amount of both ALA and LA statistically decrease. The question is whether drinking large amounts of Yerba Mate will have a positive influence on our body. On the one hand, we see a positive impact in the prevention of many civilization diseases $[1,3,4,5]$. On the other hand, we are finding more and more reports about a positive correlation between consumption of Yerba Mate and cancer incidence [1]. It is probable that higher risk of cancer incidence (mostly of the head and neck) is associated with high temperature of infusion [23]. Our study demonstrated that there are no significant differences in the amount of alpha-linolenic acid in the cold and the hot brews. In the case of linoleic acid, the cold drink even contains a significantly higher concentration of the acid. This means that drinking cold Yerba Mate we are able to eliminate one of the carcinogenic factors without losing the essential fatty acids. In addition, high temperature promotes fatty acid oxidation, which changes their healthy properties [23].

\section{CONCLUSIONS}

Drinking Yerba Mate can supply alpha-linolenic acid and linoleic acid, which are essential in a well-balanced diet. For individuals who regularly consume Yerba Mate it can be an important source of PUFA supplementation. The most preferred way to brew the tea is cold infusion, which delivers the highest dose of unchanged PUFAs. This method of brewing also reduces the gastrointestinal exposure to high temperature and thus reduces the risk of cancer incidence.

\section{REFERENCES}

1. Heck C.I., Mejia E.G.: Yerba Mate tea (Ilex pagaguariensis): A comprehensive review on chemistry, health implications, and technological considerations. J Food Sci. 2007, 7, 138-151.

2. Filip R., Ferrano G.E.: Researching on new species of "Mate": Ilex breicuspis: phytochemical and pharmacology study. Eur J Nutr. 2003, 42, 50-54.

3. Gonzalez A., Ferreira F., Vazguez A., Moyna P., Paz E.A.: Biological screeninig of Uruguayan medicanal - plants. J Ethnopharmacol. 1993, 39, 217-220.

4. Schinella G., Fantinelli J.C., Mosca S.M.: Cardioprotective effects of Ilex paraguariensis extract: evidence for a nitric oxide-dependent mechanism. Clin Nutr. 2005, 24, 360-366.

5. Filip R., Lotito S.B., Ferraro G., Fraga C.G.: Antioxidant of Ilex paraguariensis and related species. Nutr Res. 2000, 20, 1437-1446.

6. Ramirez-Mares M.V., Chandra S., De Mejia E.G.: In vitro chemopreventive activity of Camellia sinensis, Ilex paraguariensis and Ardisiacompressa tea extracts and selected polyphenols. Mutat Res. 2004, 554, 53-64.

7. López D., García-Maroto F.: Plants as 'chemical factories' for the production of polyunsaturated fatty acid. Biotechnol Adv. 2000, 18, 481-497.

8. Calder P.: Omega-3 fatty acids and inflammatory processes. Nutrients. 2010, 2, 355-374.

9. Walczewska A., Stępien T., Bewicz-Binkowska D., Zgórzyńska E.: The role of docosahexaenoic acid in neuronal function. Postępy Hig Med Dośw. 2011, 65, 314-327.

10. James M.J., Gibson R.A., Cleland L.G.: Dietary polyunsaturated fatty acids and inflammatory mediator production. Am J Clin Nutr. 2000, 71, 343.

11. Khanapure S.P., Garvey D.S., Janero D.R., Letts L.G.: Eicosanoids in inflammation: biosynthesis, pharmacology, and therapeutic frontiers. Curr Top Med Chem. 2007, 7, 311-340.

12. Bozza P.T., Bakker-Abreu I., Navarro-Xavier R.A., Bandeira-Melo C.: Lipid body function in eicosanoid synthesis: an update. Prostaglandies Leukot Essent Fatty Acids. 2011, 85, 205-213.

13. Folch J., Lees M., Sloane G.H.: A simple method for the isolation and purification of total lipids from animal tissues. J Biol Chem. 1957, 226, 497-509.

14. Russo G.L.: Dietary n- 6 and n-3 polyunsaturated fatty acids: From biochemistry to clinical implications in cardiovascularn prevention. Biochem Pharmacol. 2009, 77, 937-946.

15. Bresson J.L., Flynn A., Heinonen M., Hulshof K.: Reference intake values for n-3 and n-6 polyunsaturated fatty acids. EFSA J. 2009, 1176, 1-12.

16. Elmadfa I., Freising H., Novak V., Hofstädter D., Hasenegger V., Ferge M.: Österreichischer Ernährungsbericht. Auflage, Wien 2008, 1.

17. Astorg P., Arnault N., Czernichow S. et al.: Intake levels and food sources for the principal n- 6 and n-3 polyunsaturated fatty acids of the adult population in France. Cahiers de Nutrition et de Diététique. 2005, 40, 260-269.

18. The National FINDIET 2007 Survey. Report B23/2008. Eds: M. Paturi, H. Tapanainen, H. Reinivuo, P. Pietinen. KTL-National Public Health Institute, Helsinki 2008.

19. Kruizinga A.G., Westenbrink S., Bosch L.M.C. et al.: De inneming van Omega-3 and -6 vetzuren en van vitamines A, D en E bijjongvolwassenen. Aanvullende berekeningen op basis van Voedselconsumptiepeiling 2003. TNO rapport V7451. Zeist: TNO KvL. 2007.

20. Becker W., Pearson M.: Riksmaten 1997-1998. Befolkningenskostvanoroch näringsintag. Metod-ochresultatanalys. Livsmedelsverket, Uppsala 2002.

21. Simopoulos A.P.: The importance of the omega-6/omega-3 fatty acid ratio in cardiovascular disease and other chronic diseases. Exp Biol Med. 2008, 233, 674-688.

22. Loria D., Barrios E., Zanetti R.: Cancer and yerba mate consumption: a review of possible associations. Rev Panam Salud Publica. 2009, 25, 530-539.

23. Maskan M., Karatas S.: Fatty acid oxidation of pistachio nuts stored under various atmospheric conditions and different temperatures. J Sci Food Agric. 1998, 77, 334-340. 